\title{
Loss of Hextuple Resistance to Aminoglycoside Antibiotics in Mycobacterium tuberculosis (H37R V) by Mutation to Isoniazid Resistance and by Incubation at High Temperature
}

\author{
By MICHIO TSUKAMURA \\ The National Chubu Hospital, Obu, Aichi, Japan 474 \\ (Received Io August 1976; revised 4 October 1976)

\section{INTRODUCTION}

Tsukamura \& Mizuno (I975) reported that various types of multi-resistant mutants could be isolated by single-step selection from the H37RV strain of Mycobacterium tuberculosis, which had not been exposed previously to any antibiotic. Hextuply-resistant mutants (6R mutants), which are resistant to high concentrations of six aminoglycoside antibiotics, emviomycin (tuberactinomycin $\mathrm{N}$ ), viomycin, capreomycin, kanamycin, lividomycin and paromomycin, were thought to be produced by a single mutation. This paper describes studies carried out on the $6 \mathrm{R}$ mutants, which lose their hextuple resistance on mutation to isoniazid resistance and on incubation at $45^{\circ} \mathrm{C}$.

\section{METHODS}

Strain. All mutants were isolated from the H37Rv strain of Mycobacterium tuberculosis. They were all derived from single colonies, and all resistant mutants were isolated by singlestep selection, unless otherwise stated. Three 6R mutants (05077, 05078 and 05079) were isolated from media containing paromomycin $\left(\mathrm{I} \mathrm{m} \mathrm{ml}^{-1}\right)$. Isoniazid-resistant mutants were obtained from them by selection on medium containing isoniazid (ro $\mu \mathrm{g} \mathrm{m}^{-1}$ ). A $4 \mathrm{R}$ mutant (05083) was isolated by selection with paromomycin (I mg ml-1). Mutant 05009 was isolated by two-step selection, first with $10 \mu \mathrm{g}$ isoniazid $\mathrm{ml}^{-1}$ and then with $100 \mu \mathrm{g}$ isoniazid $\mathrm{ml}^{-1}$ : it was resistant to $\mathrm{I00} \mu \mathrm{g}$ isoniazid $\mathrm{ml}^{-1}$. Mutant $0502 \mathrm{I}$ was isolated using $\mathrm{I0} \mu \mathrm{g}$ isoniazid $\mathrm{ml}^{-1}$ and was resistant to $\mathrm{ro} \mu \mathrm{g}$ isoniazid $\mathrm{ml}^{-1}$.

Measurement of resistance levels. The antibiotics and methods were mainly those used previously (Tsukamura \& Mizuno, I975), except for a simplified method for measuring resistance. One loopful (about $0 \cdot 2 \mathrm{mg}$ moist weight) of the test strain was inoculated on to Ogawa egg medium slants containing various concentrations of the antibiotics and incubated at $37^{\circ} \mathrm{C}$ for 3 weeks. The resistance levels were taken to be the highest antibiotic concentration at which the test organism showed the same growth as on control medium without the drug. The method gave almost the same results as the quantitative method used previously.

Emviomycin (previously called tuberactinomycin N), viomycin, capreomycin, kanamycin, lividomycin, and paromomycin were used at concentrations of $0,100,200,500$ and $1000 \mu \mathrm{g} \mathrm{ml}^{-1}$. The concentrations of isoniazid (Shionogi Co., Osaka, Japan) were $0,0 . \mathrm{I}, \mathrm{I}$, 10 and $100 \mu \mathrm{g} \mathrm{ml}^{-1}$.

Incubation at $45^{\circ} \mathrm{C}$. Two types of experiments were carried out. (I) The test strain was inoculated on to Ogawa egg medium slants and incubated at $37^{\circ} \mathrm{C}$ for 3 weeks before trans- 
ferring the slants to an incubator at $45^{\circ} \mathrm{C}$. Immediately, and after I, 2 and 3 days incubation, a bacterial suspension (Io $\mathrm{mg}$ wet $\mathrm{wt}^{-1}$ ) was prepared and inoculated with a spiral loop $(0.02 \mathrm{ml})$ on to media containing various concentrations of antibiotics to determine resistance levels.

(2) A bacterial suspension ( $\mathrm{I} \mathrm{ml}$; $10 \mathrm{mg}$ wet $\mathrm{wt} \mathrm{ml}^{-1}$ ) was added to modified Sauton medium $(5 \mathrm{ml})$ and the mixture was incubated at $45^{\circ} \mathrm{C}$. Immediately, and after $3,6,24$ and $48 \mathrm{~h}$, it was inoculated with the spiral loop on to the media containing various concentrations of antibiotics. The modified Sauton medium contained: sodium glutamate, $4.0 \mathrm{~g}$; glycerol, $30 \mathrm{ml} ; \mathrm{KH}_{2} \mathrm{PO}_{4}, 0.5 \mathrm{~g} ; \mathrm{MgSO}_{4} .7 \mathrm{H}_{2} \mathrm{O}, 0.5 \mathrm{~g}$; ferric ammonium citrate, $0.05 \mathrm{~g}$; citric acid, $2.0 \mathrm{~g}$; purified agar, $20.0 \mathrm{~g}$; distilled water, $970 \mathrm{ml}$. The $\mathrm{pH}$ was adjusted to 7.0 by adding $10 \%(\mathrm{w} / \mathrm{v}) \mathrm{KOH}$ solution and the medium was sterilized by autoclaving at $120^{\circ} \mathrm{C}$ for $20 \mathrm{~min}$.

Designation of phenotypes. The phenotypes were defined according to the numbers of antibiotics to which they were resistant (see Tsukamura \& Mizuno, I975). Four subtypes of the $6 R$ phenotype had previously been distinguished, $6 R, 6 R^{\prime}, 6 R^{\prime \prime}$ and $6 R^{\prime \prime \prime}$, the last three being considered modifications of the $6 R$ phenotype. However, all the $6 R$ strains resembled the $6 R^{\prime \prime}$ phenotype after several transfers on medium containing no drug and in the present study were all designated as $6 \mathrm{R}$.

\section{RESULTS}

\section{Effect of mutation to isoniazid resistance}

The three $6 \mathrm{R}$ mutants, 05077,05078 and 05079 , were inoculated on to media containing isoniazid ( $10 \mu \mathrm{g} \mathrm{ml}^{-1}$ ). Isoniazid-resistant mutants occurred at a frequency of $\mathrm{I}$ to 2 in $10^{6}$ of the total viable population. Single colonies were subcultured on medium without any drug and tested for their phenotype. Out of 35 isoniazid-resistant mutants tested, $29(83 \%)$ had lost their hextuple resistance and the remaining six ( $17 \%$ ) maintained their 6R phenotype.

Attempts were made to isolate back mutations to the 6R phenotype from these isoniazidresistant hextuply-sensitive mutants. Out of $\mathrm{I} 2$ colonies of a revertant (05077-INH R) that survived on medium containing paromomycin ( $\mathrm{I} \mathrm{mg} \mathrm{ml}{ }^{-1}$ ), two were $6 \mathrm{R}$ mutants and the remaining Io were $4 \mathrm{R}$ mutants. Out of 30 colonies of another revertant strain (05079-INH R) that survived on the same medium, none were $6 \mathrm{R}$ mutants; all 30 colonies had the $4 \mathrm{R}$ phenotype. The numbers of surviving colonies on the medium containing paromomycin (I $\mathrm{mg}$ $\mathrm{ml}^{-1}$ ) were $\mathrm{I} 83$ and 72 out of $10^{9}$ viable bacteria for strains 05077 and 05079 , respectively.

With the parent $\mathrm{H} 37 \mathrm{RV}$ strain, the number of surviving colonies on medium containing paromomycin (I mg ml${ }^{-1}$ ) was I 45 out of $10^{9}$ viable bacteria; of 56 such colonies, 33 were of the $6 \mathrm{R}$ phenotype, $\mathrm{I} 4$ the $4 \mathrm{R}$ phenotype, and nine the ${ }_{3} \mathrm{Ra}$ phenotype (Tsukamura \& Mizuno, 1975). Thus, the frequency of the 6R mutants in the revertants appeared to be less than that of the parent $\mathrm{H} 37 \mathrm{RV}$ strain.

For comparison, isoniazid-resistant mutants were selected from the $4 \mathrm{R}$ strain (05083). Isoniazid resistance occurred at a frequency of $9 \times 10^{-6}$. Of 15 mutants derived from single colonies surviving on medium containing isoniazid ( $10 \mu \mathrm{g} \mathrm{ml}^{-1}$ ), all retained their quadruple resistance.

The loss of hextuple resistance that occurred in $6 \mathrm{R}$ strains on mutation to isoniazid resistance suggested that isoniazid-resistant strains would have diminished capacity to develop hextuple resistance. To test this possibility, mutants of the $6 \mathrm{R}$ type were selected from two isoniazid-resistant mutants (05009 and 0502I) by their resistance to lividomycin or paromomycin ( $\mathrm{I} \mathrm{mg} \mathrm{ml}^{-1}$ ). However, $6 \mathrm{R}$ mutants were produced from isoniazid-resistant strains as readily as from the parent $\mathrm{H} 3 \mathrm{RRV}_{\mathrm{R}}$ strain (Table $\mathrm{I}$ ). 
Table I. Phenotype of aminoglycoside-resistant strains isolated from isoniazid-resistant strains by single-step selection with lividomycin (I $\mathrm{mg} \mathrm{ml}^{-1}$ ) or paromomycin (I $\mathrm{mg} \mathrm{ml}^{-1}$ )

\begin{tabular}{|c|c|c|c|c|c|c|}
\hline \multirow[b]{2}{*}{ Strain } & \multirow[b]{2}{*}{$\begin{array}{l}\text { Antibiotic used } \\
\text { for selection }\end{array}$} & \multirow{2}{*}{$\begin{array}{l}\text { No. of } \\
\text { surviving } \\
\text { colonies* }\end{array}$} & \multicolumn{3}{|c|}{$\begin{array}{l}\text { No. of resistant strains } \\
\text { identified of each phenotype: }\end{array}$} & \multirow{2}{*}{$\begin{array}{c}\text { No. of } \\
\text { strains tested }\end{array}$} \\
\hline & & & 6R-INH R & 4R-INH R & 3Ra-INH R & \\
\hline 05009 & $\begin{array}{l}\text { Lividomycin } \\
\text { Paromomycin }\end{array}$ & $\begin{array}{l}30 \\
88\end{array}$ & $\begin{array}{l}16 \\
15\end{array}$ & $\begin{array}{r}3 \\
32\end{array}$ & $\begin{array}{l}\text { I } \\
3\end{array}$ & $\begin{array}{l}20 \\
50\end{array}$ \\
\hline 05021 & $\begin{array}{l}\text { Lividomycin } \\
\text { Paromomycin }\end{array}$ & $\begin{array}{r}53 \\
171\end{array}$ & $\begin{array}{l}12 \\
11\end{array}$ & $\begin{array}{r}\text { I } \\
38\end{array}$ & $\begin{array}{l}2 \\
\text { I }\end{array}$ & $\begin{array}{l}15 \\
50\end{array}$ \\
\hline $\mathrm{H} 37 \mathrm{RV}$ & $\begin{array}{l}\text { Lividomycin } \\
\text { Paromomycin }\end{array}$ & $\begin{array}{r}21 \\
145\end{array}$ & $\begin{array}{r}3 \\
33\end{array}$ & $\begin{array}{r}9 \\
14\end{array}$ & $\begin{array}{l}0 \\
9\end{array}$ & $\begin{array}{l}12 \\
56\end{array}$ \\
\hline
\end{tabular}

\section{Loss of phenotype of hextuple resistance by incubation at high temperature}

Three-week-old cultures of the three $6 \mathrm{R}$ mutants were incubated at $45^{\circ} \mathrm{C}$. At intervals, the mutants were inoculated on media containing various concentrations of the six antibiotics. They appeared to lose their resistance after 2 to 3 days (method I) or 24 to $48 \mathrm{~h}$ (method 2). Ten colonies were isolated from each strain and were shown to be susceptible to all six antibiotics. These sensitive colonies had a white, smooth appearance unlike the rough original $\mathrm{H} 37 \mathrm{RV}$ strain. Like the latter, they were acid-fast, reduced nitrate and produced niacin.

The same experiment was carried out with the $4 \mathrm{R}$ strain, but no loss of quadruple resistance occurred.

To exclude the possibility that spontaneous antibiotic-sensitive revertants which had been derived from the $6 \mathrm{R}$ mutants were more resistant to heating than their parents, the resistance to heating of the original $\mathrm{H} 37 \mathrm{Rv}$ strain was compared with that of the multi-resistant strains. The heat resistance of the strains was similar; the numbers of viable organisms were reduced by about $10^{3}$ after 3 days incubation. It was concluded that these antibioticsensitive mutants were not the result of a selective mechanism but of a conversion of hextuply-resistant mutants to susceptible organisms by heat. The change seemed to occur under the condition in which the number of viable organisms of the $6 \mathrm{R}$ strains had decreased to $0.1 \%$.

Three 6R strains were incubated in $0.067 \mathrm{M}$-phosphate buffer $(\mathrm{pH} 7 \cdot \mathrm{I})$ containing 0.01 , $0 . \mathrm{I}$ and I \% (w/v) acrinol (6,9-diamino-2-ethoxy-acridine lactate hydrate) for 3 to $72 \mathrm{~h}$, but no loss of the $6 \mathrm{R}$ phenotype occurred. The rates of o ccurrence of doubly-resistant mutants were estimated in mixed cultures of a $6 \mathrm{R}$ strain with a streptomycin-resistant strain, a rifampicin-resistant strain or an isoniazid-resistant strain, but no significant increase of the prevalence of doubly-resistant mutants (kanamycin-streptomycin, kanamycin-rifampicin, or kanamycin-isoniazid) was observed.

\section{DISCUSSION}

In this study, we have shown that $6 \mathrm{R}$ mutants lost their hextuple resistance after mutation to isoniazid resistance. The mutation to isoniazid resistance in M. tuberculosis is known to be accompanied by modification of other characters, for example, decrease in the uptake of isoniazid (Barclay, Ebert \& Koch-Weser, I953), attenuation of virulence for guinea pigs (Peizer, Widelock \& Klein, I953; Middlebrook \& Cohn, 1953; Mitchison, 1954), decrease 
in catalase activity (Middlebrook, 1954), decrease in peroxidase activity (Tirunarayanan \& Vischer, 1957), increased susceptibility in nitrofurans (Beutner, Doyle \& Evander, 1963), and increased susceptibility to $p$-aminophenol (Tsukamura \& Tsukamura, 1964). Furthermore, the phenotype of isoniazid resistance appears promptly without phenomic lag, unlike the phenotype of streptomycin resistance (Tsukamura, 1962). All these findings suggest that the mutation to isoniazid resistance involves a deletion in the genome and occurs without re-organization or synthesis of enzymes, and that the deletion is accompanied by deletion of other genes.

Jones \& David (1972) found that one type of streptomycin resistance in $M$. smegmatis was apparently carried by a plasmid. It is possible that hextuple resistance in $M$. tuberculosis is conferred by a plasmid which is lost during mutation to isoniazid resistance, and is eliminated by heating, as are some plasmids of Staphylococcus aureus (Lacey, 1975). Unlike streptomycin resistance in $M$. smegmatis, however, hextuple resistance is not 'cured' by acrinol.

\section{REFERENCES}

Barclay, W. R., Ebert, R. H. \& Koch-Weser, D. (1953). Mode of action of isoniazid. American Review of Tuberculosis and Pulmonary Diseases 67, 490-496.

Beutner, E. H., Doyle, W. M. \& Evander, L. C. (1963). Collateral susceptibility of isoniazid-resistant tubercle bacilli to nitrofurans. American Review of Respiratory Diseases 88, 712-715.

JONES, W. D. \& DAVID, H. L. (1972). Preliminary observations on the occurrence of a streptomycin R-factor in Mycobacterium smegmatis ATCC 607. Tubercle 53, 35-42.

LACEY, R. W. (1975). Antibiotic resistance plasmids of Staphylococcus aureus and their clinical importance. Bacteriological Reviews 39, I-32.

MIDDLEBROOK, G. (1954). Isoniazid-resistance and catalase activity of tubercle bacilli. A preliminary report. American Review of Tuberculosis and Pulmonary Diseases 69, 47I-474.

MidDlebrook, G. \& COHN, M. L. (I953). Some observations on the pathogenicity of isoniazid-resistant variants of tubercle bacilli. Science 118, 297-299.

Mitchison, D. A. (1954). Tubercle bacilli resistant to isoniazid. British Medical Journal no. 4854, I28-1 30.

Peizer, L. R., Widelock, D. \& KieIN, S. (I953). Virulence in guinea pigs of isoniazid-resistant cultures isolated from clinical specimens. A preliminary report. American Review of Tuberculosis and Pulmonary Diseases 68, 290-29I.

Tirunarayanan, M. O. \& Vischer, W. A. (1957). Relationship of isoniazid to the metabolism of mycobacteria. Catalase and peroxidase. American Review of Tuberculosis and Pulmonary Diseases 75, 62-70.

TsukAmURA, M. (1962). Mutations and inactivation of mycobacteria induced by ultraviolet irradiation. Japanese Journal of Tuberculosis 10, I-14.

Tsukamura, M. \& Mizuno, S. (1975). Cross-resistance relationships among the aminoglucoside antibiotics in Mycobacterium tuberculosis. Journal of General Microbiology 88, 269-274.

Tsukamura, M. \& TsukamuRa, S. (1964). Increased susceptibility of isoniazid-resistant Mycobacterium tuberculosis to $p$-aminophenol. Acta tuberculosea et pneumologica scandinavica 44, 99-IOI. 